на здобуття науковго ступеня канд. пед. наук : спец. 13.00.02 «Теорія і методика навчання (українська література)» [Електронний ресурс] / Бабійчук Тамара Василівна. - Київ, 2007. Режим доступу : http://librar.org.ua/sections_load.php?s= philology\&id=1759\&start=6 2. Гельмонт А. Кино на уроке: Кино как наглядное пособие и общая методика его применения / А. Гельмонт. - Москва : Изд-во АПН РСФСР, 1961. - 102 с. 3. Прессман Л. Дидактические основы применения экранно-звуковых средств в школе/ Л. Прессман.Москва : Педагогика, 1987. - 152 с. 4. Рабинович Р. Фильмы-экранизации на уроках литературы и воспитание художественного вкуса у старшеклассников / Р. Рабинович// Искусство в школе. - Москва : Просвещение, 1964. - С. 224-250.

УДК 378.147

Іван Касілов

\title{
РОЗВИТОК ВИКОНАВСЬКОЇ ТЕХНІКИ СТУДЕНТІВ-ГІТАРИСТІВ У ПРОЦЕСІ НАВЧАННЯ НА ФАКУЛЬТЕТІ МИСТЕЦТВ
}

Касілов І. А. Розвиток виконавської техніки студентів-гітаристів у процесі навчання на факультеті мистецтв.

У статті висвітлено основні проблеми становлення та розвитку виконавської техніки, а також загального професійного рівня майстерності гри на шестиструнній класичній гітарі в умовах освітньої програми України. Розкрито історичні особливості виникнення інструменту та розглянуто методичні шляхи розв'язання основних виконавських задач.

Ключові слова: прийоми звуковидобування, специфіка звукоутворення, ігровий апарат, приготовлені та робочі рухи.

Касилов И. А. Развитие исполнительской техники студентов-гитаристов в процессе обучения на факультете искусств.

В статье освещены основные проблемы становления и развития исполнительской техники, а также общего профессионального уровня мастерства игры на шестиструнной гитаре в условиях образовательной программы в Украине. Раскрыты исторические особенности возникновения инструмента и рассмотрены методические пути разрешения основных исполнительских задач.

Ключевые слова: приёмы звукоизвлечения, специфика звукообразования, игровой аппарат, приготовленные и рабочие движения.

Kasilov I. A. The development of students' performance abilities in learning guitar at the faculty of Arts.

The article deals with the main problems of formation and development of performance technique as well as the common professional level in playing six-string classical guitar in the context of educational program in Ukraine. The historical features of musical instrument appearance are given as well as the methodical ways for the solution of the main performing problems are considered.

Key words: methods of phonation, sound creation specific features, musical instrument, movements of preparing and working basis.

У контексті сучасної освітньої програми стає актуальною проблема фахової підготовки студентів в умовах педагогічних навчальних закладів. Зростання сучасних вимог 
щодо програми національної освіти актуалізує низку питань, які повинні відповідати вдосконаленню професійного рівня майбутнього педагога мистецьких дисциплін у закладах освіти.

За останнє століття мистецтво гри на шестиструнній класичній гітарі набуло неабиякої популярності як у концертних заходах нашого часу, так і в галузі культурного та освітнього життя, а це означає, що теорія формування виконавської майстерності потребує нової інтерпретації щодо методики викладання гри на шестиструнній гітарі у класі 3 основного та додаткового інструментів. Сучасні вимоги щодо виконавського гітарного мистецтва в умовах музично-педагогічної освіти потребують загального перегляду та розроблення значної кількості методичних питань, які б могли розв'язати поставлені задачі в контексті сучасної освітньої парадигми.

Починаючи з середини XIX-го століття, для шестиструнної гітари було написано багато вітчизняних та зарубіжних збірок, які намагалися в дуже стислій форми розглянути й розв'язати питання щодо оволодіння основними технічними прийомами гри на інструменті. 3-поміж найбільш відомих можна назвати «Школу гри на шестиструнній гітарі» за редакцією А. Іванова-Крамського, «Акорди та акомпанемент на шестиструнній гітарі» за редакцією П. Вещицького. Найбільш відомими є зарубіжні школи Е. Пухоля, М. Каркассі та багато інших. Незважаючи на чітку послідовність використання технічного матеріалу, який подається у вигляді гам, вправ та етюдів, написаних самими авторами, виникає багато питань щодо висвітлення теоретичного матеріалу, використання оригінальних художніх творів, які б сприяли закріпленню технічних навичок виконавця, а також, методичного підходу до поставлених питань, які потребують подальшого роз'яснення та розв'язання. Такий підхід можна назвати методом анатомо-фізіологічного підходу, який базується на відчутті хаотичних та необумовлених рухів. Характерним для такого підходу є механічність вправ, відсутність методичного обгрунтування у розв'язанні технічних питань, недостатня кількість оригінальних творів художнього характеру для закріплення набутих технічних навичок. У такий спосіб окреслений метод навчання гри на шестиструнній гітарі порушує принцип формування професійного підходу щодо виконання на інструменті та не відповідає гармонійній єдності художнього і технічного розвитку музиканта.

Mema cmammi - створити чітку систематизацію теоретичного висвітлення окремих методичних питань, які допоможуть розв'язати основні проблеми технічного розвитку студентів під час індивідуальних занять 3 основного та додаткового інструментів на факультеті мистецтв; сприяти створенню художнього образу під час виконання, формуванню загальної естетичної культури почуттів.

Однією із провідних рис у формуванні виконавської майстерності гітариста $€$ органічність контактування 3 інструментом. Сучасний музикант у процесі виконання повинен створювати власний художній образ, а не розв'язувати проблему механічного тренування послідовності звуків, розташованих у часі, тому слід відзначити, що значне місце у формуванні виконавської майстерності гітариста має специфіка звукоутворення та прийоми звуковидобування на інструменті.

За своїм походженням гітара належить до типу струнних щипкових інструментів, які належали до сімейства лютневих. Лютня - найбільш розповсюджений та улюблений музичний інструмент у багатьох західноєвропейських країнах доби Відродження - таких, як Німеччина, Франція, Англія, Польща, Італія та Іспанія. Ї̈̈ знали майже в усіх громадських верствах. На лютні музиканти-віртуози та знатні любителі мистецтва грали при королівських, князівських та герцогських дворах. Також їі можна було почути в домашньому 
побуті провінціальних мешканців та різних ансамблях, у тому числі театральних. Для неї писали спеціальні нові твори, а також робили переклади й обробки тих творів, які найбільше подобались слухачам, а саме: найпоширеніші пісні та танці, духовна музика відомих майстрів.

Традиції лютневої музики були досить ранніми, але спеціальні записи, зроблені для неї у вигляді окремих систем (лютневих табулятур), збереглися лише з кінця XV століття. Вони свідчать про формування окремого стилю виконання на лютні та його широке практичне використання [4, с. 285].

У XVI столітті найбільш поширеною серед лютневих інструментів стає шестиструнна лютня, яка на той час вже мала квартово-квінтовий стрій, притаманний сучасним струнним інструментам. Саме вони і стали нащадками сучасної шестиструнної класичної гітари $\mathrm{i}$ використовувалися вже у мистецькому житті суспільства як самостійні сольні інструменти. Про це свідчить творча спадщина відомого італійського композитора доби Відродження Франческо Канови да Мілано (1497-1543). Саме його рукописи у великій кількості були відомі в Італії, Франції, Нідерландах, Іспанії та досить поширено використовуються у концертних заходах нашого часу, не втрачаючи актуальності.

Поширення традицій лютневої музики на західноєвропейському культурному просторі сприяло виникненню перших, так званих «гітарних шкіл», які відомі і нині, особливо розповсюдженими є італійські школи, які базуються на принципах безопорного нігтьового способу звуковидобування - tirando, як основного, та іспанські школи, які пропонують опорний нігтьовий спосіб звуковидобування - apoyando, як основний, яким користуються сучасні гітаристи фламенко.

Технічний розвиток гітариста - досить складний рухово-координаційний комплекс, який передбачає сконцентрованість взаємопов'язаних та взаємообумовлених рухів ігрового апарату (між правою та лівою руками), які спрямовані на розв'язання та подолання труднощів у єдиному музично-ігровому процесі. Говорячи про якість виконавського процесу, треба враховувати такий важливий аспект, як прийом звукоутворення. За якісне формування звуку на класичній шестиструнній гітарі відповідає закономірність реагування струни гітари на дію виконавських прийомів, залежно від міри та ваги контактування з нею ігрового апарату.

Отже, виходячи 3 вищесказаного ми спостерігаємо, що процес звукоутворення на інструменті буде залежати від кількох взаємопов'язаних факторів, які слід розглянути більш детально, а саме:

- спосіб звукоутворення, як безпосередній контакт між пальцями правої руки та струнами інструменту;

- контактування між ігровим апаратом та струнами;

- положення кистьової частини правої руки відносно корпусу гітари, як основний складник у формуванні тембрального забарвлення й динамічних відтінків;

- приготовлені та робочі рухи ігрового апарату як запорука для економічного використання енергії м'язів правої та лівої рук.

Спосіб звукоутворення становить складний процес, обумовлений правильною та точно скоординованою роботою пальців правої руки стосовно струн інструменту. Робота пальців правої руки має велике значення у виконавській техніці гітариста. Пальці правої руки відповідають за якість утворення звуку та визначають сам спосіб звуковидобування. Способів звуковидобування на шестиструнній гітарі є досить багато, але основними та 
найбільш поширеними прийомами є опорний нігтьовий спосіб - apoyando, та безопорний нігтьовий спосіб - tirando. Ці прийоми незначною мірою відрізняються між собою, але деякі основні відмінності ми розглянемо нижче.

Apoyando - один 3 основних прийомів, яким користувалися іспанські гітаристи фламенко. Для того щоб гітарний супровід та сольний спів не заглушували ритмічного відбивання каблуків танцівника та метричний плеск у долоні інших учасників ансамблю, гітаристи фламенко потребували пошуку більш глибокого та яскравого звучання. Так виникає опорний спосіб звуковидобування, який був викликаний слабкими акустичними можливостями інструменту. Прийом apoyando виникає унаслідок удару по струні, 3 якої видобувається звук пальцем правої руки, після чого цей палець зупиняється на сусідній струні, розташованій вище. У разі такого руху палець правої руки буде більш випрямленим щодо інших пальців, які не беруть участі у звукоутворенні.

Другий, не менш важливий прийом безопорної нігтьової гри,-tirando, виникає як наслідок та необхідність технічної досконалості гітариста. Виконання акордової фактури й арпеджіо вимагає одночасного використання декількох струн для створення загального гармонійного фону. У цьому випадку опора пальців правої руки на сусідню верхню струну буде недоречною, оскільки верхня струна теж використовується під час виконання і повинна коливатися у процесі звучання. Використовуючи прийом tirando, палець правої руки створює невелику дугу в напрямі долоні і тим самим звільнює сусідню струну від опорної функції.

Контактування між ігровим апаратом та струнами. Безмежна різноманітність композиторських задумів, образно-емоційних систем, наявних у світі музичних творів усіх епох, стилів, жанрів і форм викликало велике розмаїття інтерпретаторських тлумачень та їх змісту окремими виконавцями. По суті, скільки в музиці неповторних образів, відтінків, характерів, стільки повинно бути й різноманітних неповторюваних рухів під час виконання. Секрет професійного та якісного виконання полягає у формуванні системи навичок, які будуть спрямовані на розвиток необхідної виконавської техніки.

Важливу роль у розвитку виконавської техніки гітариста відіграє свобода виконавського апарату, яка базується на питаннях контактування та взаємодії між інструментом та механічними рухами правої та лівої рук. У повсякденному житті людина звикає до безлічі рухових дій, які викликають збитковий ступінь м'язової активності. Однак під час виконання на інструменті виникає необхідність чіткої та точної концентрації ступеня навіть незначного м'язового напруження виконавця при безпосередньому контакті з самим інструментом.

Американський гітарист Чарльз Дункан говорив: «Секрет гарної координації дій полягає в тому, що для гри в цілому потрібні значні зусилля обох рук. Удосконалення техніки гри- це в багатьох випадках процес вивчення та оволодіння зусиллями, їх напрямком і фокусуванням, обмеження до мінімуму витрат енергії, необхідної для реалізації музично-технічних завдань» [3, с. 115].

Основним положенням формування виконавської техніки гітариста є одинарний та комплексний контакти з інструментом у процесі звукоутворення.

Одинарним контактом у процесі звукоутворення ми називаємо комплекс рухів пальців правої руки щодо відкритої струни, з якої треба видобувати звук. Відкрита струна у цьому випадку буде визначати точність висоти звуку, а рухові дії пальців правої руки та сила їх тиску на струну будуть спрямовані на визначення амплітуди коливання.

До одинарного контакту ми також відносимо роботу пальців окремо лівої руки у процесі звукоутворення. У цьому випадку звук утворюється за допомогою удару та 
стискування пальцем лівої руки окремої струни на площині грифу біля металевого ладу, який визначає висоту потрібного звука.

Комплексний контакт у процесі звукоутворення можна розглядати як взаємозалежність процесів утворення безпосередньо висоти звуку, яка визначається за допомогою натискання пальців лівої руки на площину грифу гітари біля металевого ладу та сили тиску на струну пальців правої руки, яка визначає амплітуду коливання струни. Говорячи про рухові дії пальців правої руки, слід відзначити, що від їхніх рухів залежить не лише амплітуда коливання струни, як запорука динамічної гучності, але й такі засоби музичної виразності як артикуляція та тембральне забарвлення.

Положення кистьової частини правої руки відносно корпусу гітари. Гітара відносно слабкий за своїми акустичними можливостями інструмент, її не можна порівнювати за шкалою динамічної градації з такими клавішними інструментами, як фортепіано, баян та акордеон, але вона значно виграє у питаннях тембрового забарвлення та природи виникнення самого звуку. Визначна роль тембрової якості звуку залежить від постановки правої руки. Усесвітньо відомий гітарист-педагог Е. Пухоль говорив: «Від положення правої руки залежить не тільки якість, сила та різнобарвлення звуків, але й рухливість пальців; ії дії визначають ритм, експресію, нюанси та всю гаму звуків, необхідних для художнього виконання» [7, с. 17].

Важливу роль у формуванні якісних характеристик звуку відіграє кутове положення кисті та пальців правої руки по відношенню до струн інструменту. Якщо кисть знаходиться перпендикулярно до струн під прямим кутом 90 градусів, звук буде формуватися різкий, підкреслений, з невеликим акцентом та в динамічному плані більш гучний. Значна різниця буде у зміні положення кисті правої руки щодо струн, якщо кут положення кисті збільшиться до 120-130 градусів і буде становити пряму лінію з передпліччям, у такому випадку атака звуку буде більш м'якою та поглибленою, а звучання буде відносно тихішим порівняно з попереднім звукоутворенням.

Слід зауважити, що кутове положення кисті та пальців відносно струн гітари не $є$ основним складником у питаннях вирішення тембрового забарвлення та динамічної шкали. Неабияку роль відіграє також безпосереднє положення кисті та пальців правої руки щодо розетки корпусу гітари та підставки у правій частині корпусу, на якій закріплюються струни. Кистьова частина та передпліччя правої руки можуть рухатись у паралельному напрямі уздовж струн від підставки до розетки гітари, а в деяких випадках і далі до грифової частини інструменту. Саме на цьому моменті зосереджував свою увагу відомий гітарист і композитор Фернандо Сор (1778-1839), діяльність якого мала велике значення для подальшого розвитку гітарного мистецтва Англії, Франції та Росії.

Природа виникнення звуку залежить від частоти коливання струни, а саме у крайніх частинах натягнутої струни воно менше, а в середній частині-більше. У такий спосіб супротив від контактування на різних ділянках пальців правої руки зі струною буде різним. Для досягнення більш різкого металевого тембру кисть правої руки треба відводити у праву частину корпусу гітари, супротив струни у цій частині буде великий. Якщо ж навпаки кистьову частину змістити ближче до розетки, то супротив струни буде значно меншим, а тембр звуку стане більш м'яким та наближеним до звучання старовинного інструменту арфи.

Підготовлені та робочі рухи ігрового апарату. Запорукою професійного оволодіння різними видами техніки під час виконання на шестиструнній гітарі є економне витрачання енергії м'язів ігрового апарату. У концертній практиці виконання на інструменті ми досить часто можемо спостерігати перенапруження м'язів через зайві рухові дії та відсутність 
досвіду в послідовності використання підготовлених та робочих рухів пальців правої та лівої рук. Що ми розуміємо під поняттям приготовлених та робочих рухів?

Під підготовленими рухами слід розуміти процес механічної дії пальців перед утворенням звуку, який безпосередньо спрямований на здійснення самого робочого руху, тобто самого процесу звукоутворення. Закономірність використання підготовленого руху полягає у створенні умов для максимального скорочення рухових дій та м'язових витрат у процесі виконання. Підготовлені рухи мають другорядне значення по відношенню до звукоутворення, але $є$ необхідною умовою для виникнення робочого руху, який і $є$ основною метою.

Під робочими рухами слід розуміти сам процес звукоутворення, який представляє собою комплекс рухових дій як правої та лівої рук одночасно, так і в окремих випадках, коли звук створюється на відкритій струні тільки за допомогою пальців правої руки, та у випадку 3 лівою рукою, коли звук створюється на грифі гітари безпосередньо пальцями лівої руки (прийом легато).

Говорячи про закономірність послідовності підготовлених та робочих рухів, ми звернемо увагу на такий важливий момент, як максимальна близькість пальців правої та лівої рук до струни інструменту.

Максимальна близькість пальців лівої та правої рук до струн гітари є необхідною умовою у процесі виконання музичного твору. Такий підхід забезпечить економію рухів через зменшення амплітуди підйому пальців над струнами та їх зворотному падінні на струну. Це означає, що м'язові скорочення під час рухових дій пальця будуть зведені до мінімуму, а значить і витрати енергії будуть значно менші. Використання такого методичного підходу буде найбільш ефективним для розвитку швидкості рухів пальців під час виконання творів у швидких темпах.

Розвиток виконавської техніки - це досить складний процес взаємодії між художньою творчістю, авторським задумом і рефлекторними діями виконавця, метою якого є логічне розкриття змісту музичного твору. Запорукою формування технічної досконалості є чіткість та послідовність засвоєння та виконання методичних правил і рекомендацій у процесі навчання. Розроблення методичних програм щодо розвитку виконавської майстерності гітариста $\epsilon$ необхідним складником професійної підготовки студентів як майбутніх викладачів музичного мистецтва. Виконавська майстерність не є вродженою якістю, а $є$ результатом цілеспрямованого вироблення вмінь і навичок гри на гітарі.

\section{Література}

1. Агафошин П. С. Школа для шестиструнной гитары / П. С. Агафошин. - Москва : Музыка, 1960. - 148 с. 2. Давидов М. А. Теоретичні основи формування виконавської майстерності баяніста : [навч. посібник для вищ. муз. навч. закладів] / М. А. Давидов. - Київ : Музична Україна, 1997. - 240 с. 3. Дункан Ч. Искусство игры на классической гитаре / Ч. Дункан. - Москва, 1990,-115 с. 4. Ливанова Т. История западноевропейской музыки до 1789 года / Т. Литвинова. - Москва : Музыка, 1983. - 696 с. 5. Михайленко М. П. Методика викладання гри на шестиструнній гітарі / М. П. Михайленко. - Київ : Книга, 2003. - 248 с. 6. Проблеми історії й теорії академічного народно-інструментального виконавства : матеріали Всеукраїнської науково-практичної конференції до 80-річчя від дня народження М. А. Давидова. - Луцьк : ВАТ «Волинська обласна друкарня», 2010. - 184 с. 7. Пухоль Э. Школа игры на шестиструнной гитаре / Э. Пухоль. - Москва : Советский композитор, 1977. 192 c. 